\title{
L'Cuvre de Victor Hugo à l'écran. Des rayons et des ombres, sous la direction de Delphine Gleizes
}

\section{Mario Richter}

\section{(2) OpenEdition}

1 Journals

\section{Edizione digitale}

URL: https://journals.openedition.org/studifrancesi/26628

DOI: 10.4000/studifrancesi.26628

ISSN: 2421-5856

\section{Editore}

Rosenberg \& Sellier

\section{Edizione cartacea}

Data di pubblicazione: 1 avril 2007

Paginazione: 204

ISSN: 0039-2944

\section{Notizia bibliografica digitale}

Mario Richter, «L'E Euvre de Victor Hugo à l'écran. Des rayons et des ombres, sous la direction de Delphine Gleizes», Studi Francesi [Online], 151 (LI | I) | 2007, online dal 30 novembre 2015, consultato il 23 novembre 2021. URL: http://journals.openedition.org/studifrancesi/26628 ; DOI: https://doi.org/ 10.4000/studifrancesi.26628

Questo documento è stato generato automaticamente il 23 novembre 2021.

\section{(c) (1)}

Studi Francesi è distribuita con Licenza Creative Commons Attribuzione - Non commerciale - Non opere derivate 4.0 Internazionale. 


\title{
L'CEuvre de Victor Hugo à l'écran. Des rayons et des ombres, sous la direction de Delphine Gleizes
}

\author{
Mario Richter
}

\section{NOTIZIA}

L'Euvre de Victor Hugo à l'écran. Des rayons et des ombres. Ouvrage publié avec le soutien de l'Université Lumière Lyon II, sous la direction de Delphine Gleizes, L'Harmattan, Les Presses de l'Université Laval, 2005, pp. 285.

1 Improntata da un impegno prevalentemente interdisciplinare, quest'opera collettiva è il risultato di un seminario nonché di una giornata di studio che ha riunito a Lione alcuni significativi studiosi di letteratura, delle arti dello spettacolo e di storia del cinema (O. Bara, m. Berner, C. Gauthier, D. Gleizes, E. Janer, A. Laster, S. Mombert, M. Moutet, S. Raffin, D. Reynaud, M. Serceau, D. Vezyroglou). Il libro fa vedere con chiarezza quanto larga e profonda fu l'influenza dell'immaginario di Victor Hugo non soltanto sulla letteratura ma anche sulle arti visive e in primo luogo sul cinema dai tempi del cinema muto fino al recente Notre-Dame de Paris di Riccardo Cocciante e Luc Plamondon. La «Filmographie» e la «Bibliographie» che concludono il volume sono un prezioso strumento che consente di accertare con precisione quali furono i costanti e intensi rapporti fra Hugo e il cinema. 